\title{
SYNTHESIS, LARVICIDAL AND ACETYLCHOLINESTERASE INHIBITORY ACTIVITIES OF CARVACROL/ THYMOL AND DERIVATIVES
}

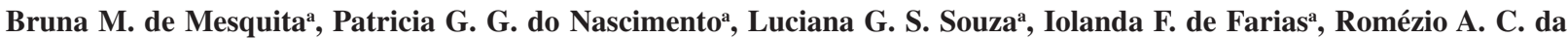
Silva $^{a}$, Telma L. G. de Lemos ${ }^{a}$, , Francisco J. Q. Monte ${ }^{a}$, Irvila R. Oliveira ${ }^{a}$, Maria T. S. Trevisan ${ }^{a}$, Horlando C. da Silva ${ }^{a}$ and Gilvandete M. P. Santiago ${ }^{\mathrm{b}}$

aDepartamento de Química Orgânica e Inorgânica, Universidade Federal do Ceará, Campus do Pici, 60021-940 Fortaleza - CE, Brasil

'Departamento de Farmácia, Universidade Federal do Ceará, Campus Porangabussu, 60430-370 Fortaleza - CE, Brasil

Recebido em 25/09/2017; aceito em 11/12/2017; publicado na web em 01/02/2018

\begin{abstract}
In order to produce bioactive derivatives of carvacrol and thymol, nine derivatives of each compound were prepared through modifications the phenolic hydroxyl group. The structures of compounds were confirmed by spectral data from MS, IR and NMR. Carvacrol, thymol and derivatives were submitted to the evaluation of the inhibition of the enzyme acetylcholinesterase, using a colorimetric method in which the inhibition of the enzyme is measured by coloration, and larvicidal activity against Aedes aegypti. Derivatives carvacryl acetate-1b and thymyl hexanoate-2b showed the best results for the inhibition of the acetylcholinesterase enzyme, and for the larvicidal activity the derivatives $\mathbf{1 a}, \mathbf{1 b}, \mathbf{1 c}, \mathbf{3 h}, \mathbf{2 a}, \mathbf{2 b}, \mathbf{2 c}$ and $\mathbf{4 h}$ showed positive results, emphasizing compound thymyl 4-methoxybenzoate- $4 \mathbf{h}$ which showed $\mathrm{LC}_{50}$ values of $23.60 \mathrm{ppm}$, considered a very good result.
\end{abstract}

Keywords: carvacrol; thymol; acetylcholinesterase; Aedes aegypti.

\section{INTRODUCTION}

Carvacrol and thymol are substances found very often in nature and are frequent targets in the natural products. They are widely reported in research that investigates pharmacological potential, presenting several related therapeutic activities, such as antioxidant, larvicidal, antimicrobial, anti-inflammatory, cytotoxic, among others. ${ }^{1-4}$

In order to develop new drugs, it is of great interest to use bioactive natural products as a raw material in the synthesis of new compounds, seeking to increase their therapeutic capacities, besides reducing side effects and toxicity. Modifications can be made to the molecule in order to introduce groups that confer new properties, such as hydrophobicity. ${ }^{5}$

Thus, it is notable that natural products have great potential in the development of new drugs, so the synthesis of derivatives of carvacrol and thymol are extensively explored and applied in biological evaluations. Being reported antibacterial, leishmanicidal, antinociceptive, anti-inflammatory, among others activities. ${ }^{6-10}$

Dengue, zika and chikungunya are considered diseases to cause serious problems to the people of developing countries. Carvacrol/ thymol are known to has excellent activity repellant and larvicidal against Aedes aegypti. ${ }^{11-14}$
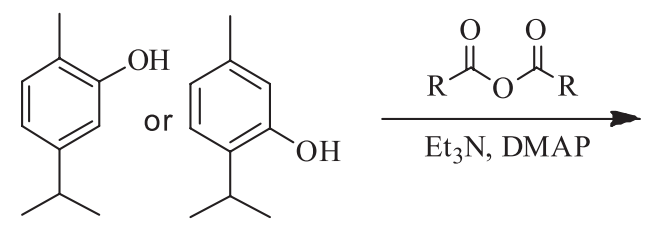

Figure 1. Synthesis of carvacrol/thymol derivatives using anhydrides
Alzheimer's disease is a progressive neurodegenerative disease, which is related to a selective loss of cholinergic neurons in the brain and reduction of levels of acetylcholine. Acetylcholinesterase inhibitors could increase levels of acetylcholine in Alzheimer's patients, alleviating some of the symptoms. ${ }^{15}$

The inhibition of acetylcholinesterase is the major mode of action for most insecticides especially organophosphates and carbamates, and this effect may be responsible for larvicidal activity on against Culex quinquefasciatus, Culex pipiens, Anopheles gambiae and Aedes aegypti. . $^{16,17}$

In this context, the aims of this study was to obtain derivatives of carvacrol/thymol and to investigate the inhibitory activity of acetylcholinesterase and larvicidal against Aedes aegypti larvae. The synthesis of the compounds was carried out according to the procedure shown in Figures 1 and 2.

\section{EXPERIMENTAL}

\section{General methods}

Reagents and solvents used were purchased from SigmaAldrich ${ }^{\circledR}$, Vetec ${ }^{\circledR}$, Synth ${ }^{\circledR}$, Tedia ${ }^{\circledR}$ and Fluka ${ }^{\circledR}$. The mass spectra were obtained on a SHIMADZUß GC-2010 Plus instrument coupled

\footnotetext{
*e-mail: tlemos@dqoi.ufc.br
}

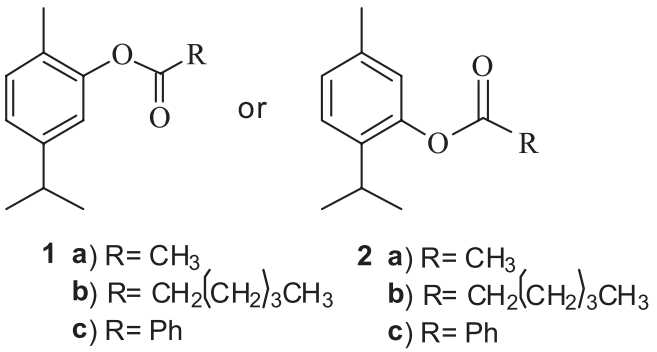



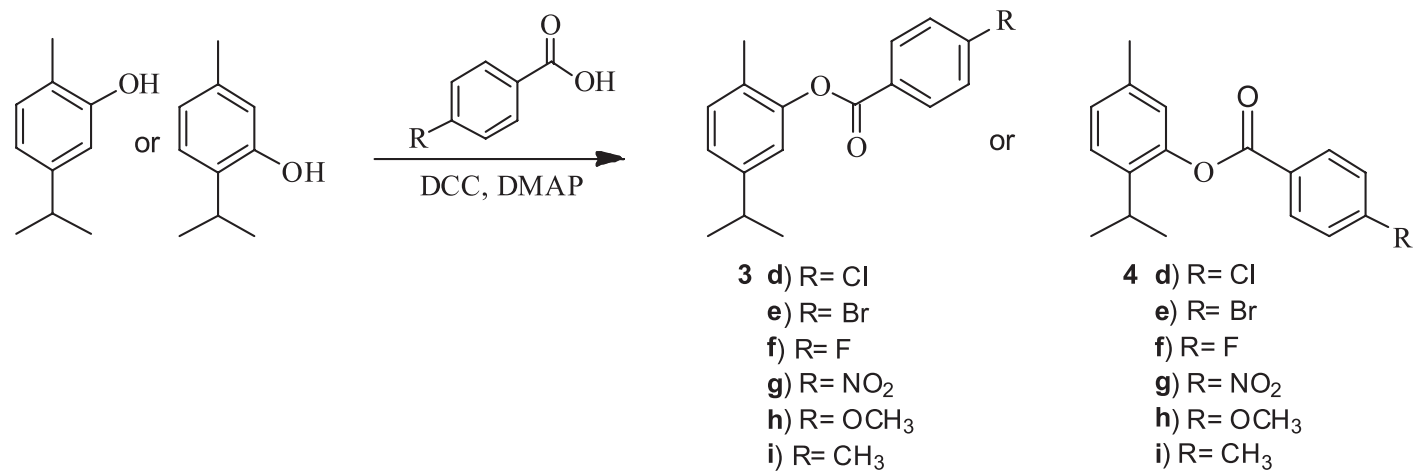

Figure 2. Synthesis of carvacrol/thymol derivatives using benzoic acid derivatives

to a GCMS-QP2010SE mass spectrometer using the RTX-5MS capillary column $(30 \mathrm{~m} \times 0.25 \mathrm{~mm} \times 0.25 \mu \mathrm{m})$ at a flow rate of

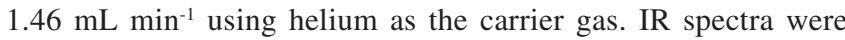
obtained on a Spectrum 1000 FT-IR. A Bruker ${ }^{\circledR}$ Advance DPX 300 spectrometer, operating at $300 \mathrm{MHz}$ for ${ }^{1} \mathrm{H}$ NMR and $75 \mathrm{MHz}$ for ${ }^{13} \mathrm{C}$ NMR, was used for the experiments of ${ }^{1} \mathrm{H}$ and ${ }^{13} \mathrm{C} \mathrm{NMR}$, using $\mathrm{CDCl}_{3}$ as solvent.

\section{GENERAL PROCEDURES FOR PREPARATION OF 1A-C AND 2A-C AND SPECTRAL DATA}

Synthesis of the derivatives was performed by the described method..$^{18} \mathrm{~A}$ mixture of different anhydrides $(1.2 \mathrm{mmol})$ and carvacrol/ thymol $(0.67 \mathrm{mmol})$ in $\mathrm{CH}_{2} \mathrm{Cl}_{2}(30 \mathrm{~mL})$ containing triethyl amine $(111 \mu \mathrm{L})$ and catalytic amount of 4-dimethylaminopyridine (DMAP) was stirred for $24 \mathrm{~h}$ at room temperature. The solution was washed with water and then, the organic phase was dried over anhydrous $\mathrm{Na}_{2} \mathrm{SO}_{4}$ and evaporated. The obtained products were purified by silica gel column chromatography with $\mathrm{CH}_{2} \mathrm{Cl}_{2}$ for $1 \mathrm{a}$ and $2 \mathrm{a}$, and $n$-hexane for $1 b, 1 \mathrm{c}, 2 \mathrm{~b}$ and $2 \mathrm{c}$.

5-isopropyl-2-methylphenyl acetate (carvacryl acetate-1a): Yield: 59\%; GC-MS: m/z 192 [M+], 177 (1), 149(2), 150(70), 135(100); IR (KBr) v/cm ${ }^{-1} 2955,1762,1508,1371,1203,900 ;{ }^{1} \mathrm{H}$ NMR $(300$ $\left.\mathrm{MHz}, \mathrm{CDCl}_{3}\right) \delta 1.24(\mathrm{~d}, 6 \mathrm{H}, J$ 6.9), $2.15(\mathrm{~s}, 3 \mathrm{H}), 2.32(\mathrm{~s}, 3 \mathrm{H}), 2.89$ (m, 1H), 6.87 (d, 1H, $J$ 1.4), 7.02 (dd, $1 \mathrm{H}, J 1.5,7.7), 7.15$ (d, $1 \mathrm{H}, J$ 7.8); ${ }^{13} \mathrm{C} \mathrm{NMR}\left(75 \mathrm{MHz}, \mathrm{CDCl}_{3}\right) \delta 15.9,21.0,24.0,33.7,119.9,124.3$, $127.3,131.1,148.3,149.5,169.5$. In agreement of literature. ${ }^{6,719}$

5-isopropyl-2-methylphenyl hexanoate (carvacryl hexanoate-1b): Yield: 91\%; GC-MS: m/z 248 [M+], 191(1), 150(100), 135(70); IR (KBr) $v / \mathrm{cm}^{-1} 2959,2870,1760,1507,1459,1226,1145,817 ;{ }^{1} \mathrm{H}$ NMR (300 MHz, $\left.\mathrm{CDCl}_{3}\right) \delta 0.95$ (t, 3H, J 6.9), 1.24 (d, 6H, J 6.9), $1.43(\mathrm{~m}, 4 \mathrm{H}), 1.80(\mathrm{~m}, 2 \mathrm{H}), 2.14(\mathrm{~s}, 3 \mathrm{H}), 2.58(\mathrm{t}, 2 \mathrm{H}, J 7.5), 2.87(\mathrm{~m}$, $1 \mathrm{H}), 6.86$ (d, 1H, J 1.3), 7.03 (dd, 1H, J 1.3, 7.8), 7.15 (d, 1H, J 7.8); ${ }^{13} \mathrm{C} \mathrm{NMR}\left(75 \mathrm{MHz}, \mathrm{CDCl}_{3}\right) \delta 14.1,16.0,22.5,24.1,24.9,31.6,33.8$, $34.5,120.0,124.2,127.3,131.0,148.2,149.5,172.3$.

5-isopropyl-2-methylphenyl benzoate (carvacryl benzoate-1c): Yield: 46\%; GC-MS: m/z 254 [M+], 149(1), 105(100), 77(25); IR (KBr) $v / \mathrm{cm}^{-1}$ 2961, 2868, 1737, 1600, 1503, 1451, 1260, 1062, 707; ${ }^{1} \mathrm{H}$ NMR $\left(300 \mathrm{MHz}, \mathrm{CDCl}_{3}\right) \delta 1.27$ (d, 6H, J 6.9), 2.22 (s, 3H), 2.92 $(\mathrm{m}, 1 \mathrm{H}), 7.02(\mathrm{~s}, 1 \mathrm{H}), 7.10(\mathrm{~d}, 1 \mathrm{H}, J 7.8), 7.20(\mathrm{~d}, 1 \mathrm{H}, J 7.8), 7.53$ (t, 2H, J 7.6), 7.67 (t, 1H, J 7.4), 8.24 (d, 2H, $J 74) ;{ }^{13} \mathrm{C}$ NMR (75 $\left.\mathrm{MHz}, \mathrm{CDCl}_{3}\right) \delta 16.0,24.1,33.8,120.1,124.4,127.6,128.8,129.8$, $130.4,131.1,133.7,148.3,149.7,165.1$. In agreement of literature.

2-isopropyl-5-methylphenyl acetate (thymyl acetate-2a): Yield: 55\%; GC-MS: m/z 192 [M+], 150(40), 135(100), 115(5); IR (KBr) v/cm ${ }^{-1} 2962,2870,1762,1623,1369,1369,1209,1087,898,817$; ${ }^{1} \mathrm{H}$ NMR (300 MHz, $\left.\mathrm{CDCl}_{3}\right) \delta 1.23(\mathrm{~d}, 6 \mathrm{H}, J$ 6.9), 2.33 (s, 6H), 2.98 (m, 1H), 6.82 (br s, 1H), 7.04 (d, 1H, J 7.9), $7.21(\mathrm{~d}, 1 \mathrm{H}, J 7.9) ;{ }^{13} \mathrm{C}$ NMR ( $\left.75 \mathrm{MHz}, \mathrm{CDCl}_{3}\right) \delta 21.0,21.1,23.2,27.4,122.9,126.6,127.3$, $136.7,137.2,148.1,170.0$. In agreement of literature. ${ }^{7,9}$

2-isopropyl-5-methylphenyl hexanoate (thymyl hexanoate-2b): Yield: 74\%; GC-MS: m/z 248 [M+], 150(80), 135(100), 115(3); IR (KBr) v/cm ${ }^{-1} 2959,2926,2870,1760,1621,1505,1151,815 ;{ }^{1} \mathrm{H}$ NMR (300 MHz, $\left.\mathrm{CDCl}_{3}\right) \delta 0.95$ (t, 3H, J 7.0), 1.20 (d, 6H, J 1.2), $1.43(\mathrm{~m}, 4 \mathrm{H}), 1.80(\mathrm{~m}, 2 \mathrm{H}), 2.32(\mathrm{~s}, 3 \mathrm{H}), 2.58(\mathrm{t}, 2 \mathrm{H}, J$ 7.4), $2.97(\mathrm{~m}$, $1 \mathrm{H}), 6.81(\mathrm{~s}, 1 \mathrm{H}), 7.03(\mathrm{~d}, 1 \mathrm{H}, J 7.8), 7.20(\mathrm{~d}, 1 \mathrm{H}, J 7.8) ;{ }^{13} \mathrm{C} \mathrm{NMR}(75$ $\left.\mathrm{MHz}, \mathrm{CDCl}_{3}\right) \delta 14.1,21.0,22.5,23.2,24.9,27.3,31.5,34.6,123.0$, $126.5,127.2,136.7,137.6,148.2,172.7$. In agreement of literature. ${ }^{20}$

2-isopropyl-5-methylphenyl benzoate (thymyl benzoate-2c): Yield: 38\%; GC-MS m/z 254 [M+], 149(30), 105(100), 77(40); IR (KBr) $v / \mathrm{cm}^{-1} 3030,2962,2924,2868,1733,1600,1451,1236,817$, 708; ${ }^{1} \mathrm{H} \mathrm{NMR}\left(300 \mathrm{MHz}, \mathrm{CDCl}_{3}\right) \delta 1.23$ (d, 6H, J 6.9), $2.36(\mathrm{~s}, 3 \mathrm{H})$, 3.08 (m, 1H, J 6.9), 6.97 (s, 1H), 7.08 (d, 1H, J 7.9), 7.27 (d, 1H, $J$ 7.9), 7.54 (t, 2H, J 7.6), $7.66(\mathrm{t}, 1 \mathrm{H}, J 7.4), 8.24(\mathrm{~d}, 2 \mathrm{H}, J 7.4) ;{ }^{13} \mathrm{C}$ $\operatorname{NMR}\left(75 \mathrm{MHz}, \mathrm{CDCl}_{3}\right) \delta 21.0,23.2,27.5,126.7,127.3,128.8,129.9$, $130.3,133.7,136.8,137.4,148.4,165.5$. In agreement of literature. ${ }^{7,20}$

General procedures for preparation of $3 d-i$ and $4 d-i$ and spectral data

The synthesis of the derivatives were performed by the described method. ${ }^{21}$ A mixture of different benzoic acid derivatives $(2 \mathrm{mmol})$ and carvacrol/thymol $(1 \mathrm{mmol})$ in $\mathrm{CH}_{2} \mathrm{Cl}_{2}(30 \mathrm{~mL})$ containing $N$, $N$ '-diciclohexilcarbodiimida (DCC) $(2 \mathrm{mmol})$ and DMAP (2 mmol) was stirred for $4 \mathrm{~h}$ at room temperature. The solution was filtered under vacuum and solvent was evaporated. The obtained products were purified by silica gel column chromatography with $n$-hexane/ $\mathrm{CH}_{2} \mathrm{Cl}_{2}(50: 50)(\mathrm{v} / \mathrm{v})$, an fractions were analysed in TLC.

5-isopropyl-2-methylphenyl 4-chlorobenzoate (carvacryl 4-chlorobenzoate-3d): Yield: 67\%; GC-MS: $m / z, 288$ [M+], 141(35), 139(100), 113(10), 111(30); IR (KBr) v/cm ${ }^{-1} 2959,1732,1593,1503$, 1261, 1070, 753; ${ }^{1} \mathrm{H}$ NMR (300 MHz, $\left.\mathrm{CDCl}_{3}\right) \delta 1.27$ (d, 6H, J 6.9), $2.20(\mathrm{~s}, 3 \mathrm{H}), 2.92(\mathrm{~m}, 1 \mathrm{H}), 7.01(\mathrm{~s}, 1 \mathrm{H}), 7.08(\mathrm{~d}, 1 \mathrm{H}, J$ 7.8), 7.21 (d, 1H, J 7.7), 7.51 (d, 2H, J 7.7), 8.32 (d, 2H, $J$ 7.7); ${ }^{13} \mathrm{C}$ NMR (75 $\left.\mathrm{MHz}, \mathrm{CDCl}_{3}\right) \delta 16.0,24.1,33.8,120.0,124.5,127.5,128.5,129.2$, $131.2,131.7,149.5,164.2$.

5-isopropyl-2-methylphenyl 4-bromobenzoate (carvacryl 4-bromobenzoate-3e): Yield: 64\%; GC-MS: m/z 332 [M+1, 185(100), 183(100), 155(20), 153(20); IR (KBr) v/cm ${ }^{-1} 2960,1738,1589,1503$, 1261, 1073; ${ }^{1} \mathrm{H}$ NMR (300 MHz, $\mathrm{CDCl}_{3}$ ) $\delta 1.27$ (d, 6H, J 6.9), 2.19 
(s, 3H), $2.92(\mathrm{~m}, 1 \mathrm{H}), 7.00(\mathrm{~s}, 1 \mathrm{H}), 7.08(\mathrm{~d}, 1 \mathrm{H}, J$ 7.7), $7.21(\mathrm{~d}, 1 \mathrm{H}$, $J$ 7.7), 7.68 (d, 2H, $J$ 8.4), 8.09 (d, 2H, $J 8.4) ;{ }^{13} \mathrm{C} \mathrm{NMR} \mathrm{(75} \mathrm{MHz,}$ $\left.\mathrm{CDCl}_{3}\right) \delta 16.0,24.1,33.8,120.0,124.5,127.4,128.8,128.9,131.2$, $131.8,132.1,148.4,149.5,164.4$.

5-isopropyl-2-methylphenyl 4-fluorobenzoate (carvacryl 4-fluorobenzoate-3f): Yield: 96\%; GC-MS: m/z 272 [M+], 149(1), 123(100), 95(30); IR (KBr) v/cm ${ }^{-1} 2962,1739,1605,1508,1263$; ${ }^{1} \mathrm{H}$ NMR (300 MHz, $\mathrm{CDCl}_{3}$ ) $\delta 1.27$ (d, 6H, J 6.9), 2.20 (s, 3H), 2.92 $(\mathrm{m}, 1 \mathrm{H}), 7.01(\mathrm{~d}, 1 \mathrm{H}, J 1.3), 7.06(\mathrm{dd}, 1 \mathrm{H}, J 1.5,9.3), 7.18(\mathrm{~d}, 1 \mathrm{H})$, 7.20 (dd, 2H, J 5.5, 7.8), 8.25 (dd, $2 \mathrm{H}, J 5.5,7.8) ;{ }^{13} \mathrm{C} \mathrm{NMR}(75 \mathrm{MHz}$, $\left.\mathrm{CDCl}_{3}\right) \delta 16.0,24.1,33.8,116.0,120.0,124.5,126.1,127.5,131.2$, $132.9,148.4,149.6,164.1,166.5$.

5-isopropyl-2-methylphenyl 4-nitrobenzoate (carvacryl 4-nitrobenzoate-3g): Yield: 55\%; GC-MS: m/z, 299 [M+1, 149(5), 150(100), 122(1); IR (KBr) v/cm ${ }^{-1} 2965,1736,1524,1348,1272$, $711 ;{ }^{1} \mathrm{H} \mathrm{NMR}\left(300 \mathrm{MHz}, \mathrm{CDCl}_{3}\right) \delta 1.27$ (d, 6H, $J$ 1.6), 2.21 (s, 3H), $2.93(\mathrm{~m}, 1 \mathrm{H}), 7.02(\mathrm{~s}, 1 \mathrm{H}), 7.11(\mathrm{dd}, 1 \mathrm{H}, J 1.4,6.5), 7.23$ (d, 1H, $J$ 7.8), 8.37 (d, 2H, $J$ 8.6), 8.40 (d, 2H, $J 9.1$ ); ${ }^{13} \mathrm{C}$ NMR (75 MHz, $\left.\mathrm{CDCl}_{3}\right) \delta 16.0,24.1 .33 .8,119.8,123.9,124.9,127.2,131.3,131.4$, 135.2, 148.6, 149.3, 151.1, 163.2.

5-isopropyl-2-methylphenyl 4-methoxybenzoate (carvacryl 4-methoxybenzoate-3h): Yield: 45\%; GC-MS: m/z 284 [M+], 149(1), 135(100), 107(10); IR (KBr) v/cm ${ }^{-1} 2957,1731,1607,1513,1256$, 1070, 765; ${ }^{1} \mathrm{H}$ NMR (300 MHz, $\left.\mathrm{CDCl}_{3}\right) \delta 1.28$ (d, 6H, $J$ 6.9), 2.21 (s, 3H), $2.93(\mathrm{~m}, 1 \mathrm{H}), 3.92(\mathrm{~s}, 3 \mathrm{H}), 7.02$, (t, 3H), 7.07 (d, 1H, J 7.8), 7.21 (d, $1 \mathrm{H}, J 7.7), 8.20$ (d, 2H, J 8.8). ${ }^{13} \mathrm{C} \mathrm{NMR}\left(75 \mathrm{MHz}, \mathrm{CDCl}_{3}\right.$ ) $\delta$ 16.0, 24.1, 33.8, 55.7, 114.1, 120.2, 122.2, 124.2, 127.7, 131.1, $132.4,148.3,149.8,164.1,164.8$. In agreement of literature..$^{22}$

5-isopropyl-2-methylphenyl 4-methylbenzoate (carvacryl 4-methylbenzoate-3i): Yield: 41\%; GC-MS: m/z 268 [M+1, 149(1), 119(100), 91(30); IR (KBr) v/cm ${ }^{-1}$ 2960, 1736, 1611, 1510, 1264, 748. ${ }^{1} \mathrm{H}$ NMR $\left(300 \mathrm{MHz}, \mathrm{CDCl}_{3}\right) \delta 1.28$ (d, 6H, J 6.9), 2,21 (s, 3H), $2.48(\mathrm{~s}, 3 \mathrm{H}), 2.93(\mathrm{~m}, 1 \mathrm{H}), 7.02(\mathrm{~s}, 1 \mathrm{H}), 7.07$ (d, 1H, J 7.8), 7.21 (d, $1 \mathrm{H}, J 7.7), 7.34$ (d, 2H, J 7.9), 8.14 (d, 2H, J 8.1); ${ }^{13} \mathrm{C}$ NMR (75 $\left.\mathrm{MHz}, \mathrm{CDCl}_{3}\right) \delta 16.0,21.9,24.1,33.8,120.2,124.3,127.1,127.6$, $127.1,130.4,131.1,144.5,148.3,149.8,165.1$.

2-isopropyl-5-methylphenyl 4-chlorobenzoate (thymyl 4-chlorobenzoate-4d): Yield: 77\%; GC-MS: $m / z, 288$ [M+], 141(30), 139(100), 113(5), 111(25); IR (KBr) v/cm ${ }^{-1} 2962,1738,1594,1504$, 1266, 755; ${ }^{1} \mathrm{H}$ NMR $\left(300 \mathrm{MHz}, \mathrm{CDCl}_{3}\right) \delta 1.23$ (d, 6H, J 6.9), 2.36 (s, $3 \mathrm{H}), 3.04(\mathrm{~m}, 1 \mathrm{H}), 6.95$ (s, 1H), 7.09 (d, 1H, J 7.9 Hz), 7.26 (d, 1H, J $7.9 \mathrm{~Hz}), 7.52$ (d, 2H, J 8.6 Hz), $8.17(\mathrm{~d}, 2 \mathrm{H}, J 8.6 \mathrm{~Hz}) ;{ }^{13} \mathrm{C}$ NMR $(75$ $\left.\mathrm{MHz}, \mathrm{CDCl}_{3}\right) \delta 21.0,23.2,27.5,123.0,126.7,127.5,128.3,129.2$, $131.7,136.9,137.3,140.3,148.2,164.7$.

2-isopropyl-5-methylphenyl 4-bromobenzoate (thymyl 4-bromobenzoate-4e): Yield: 89\%; GC-MS: m/z $332\left[\mathrm{M}^{+}\right], 185(100)$, 183(100), 155(25), 153(25), 149(80); IR (KBr) v/cm $\mathrm{cm}^{-1} 2964,1738$, 1587, 1233, 1089, 753; ${ }^{1} \mathrm{H}$ NMR (300 MHz, $\left.\mathrm{CDCl}_{3}\right) \delta 1.23(\mathrm{~d}, 6 \mathrm{H}, J$ 6.9), $2.30(\mathrm{~s}, 3 \mathrm{H}), 3.04(\mathrm{~m}, 1 \mathrm{H}), 6.95(\mathrm{~s}, 1 \mathrm{H}), 7.09$ (d, 1H, J 7.8), 7.26 (d, $1 \mathrm{H}, J 7.8), 7.38$ (d, 2H, $J$ 8.3), 8.09 (d, 2H, $J 8.3) ;{ }^{13} \mathrm{C}$ NMR $(75$ $\left.\mathrm{MHz}, \mathrm{CDCl}_{3}\right) \delta 21.0,23.2,27.5,122.9,126.7,127.5,128.8,128.9$, $131.1,132.2,136.9,137.3,148.2,164.8$.

2-isopropyl-5-methylphenyl 4-fluorobenzoate (thymyl 4-fluorobenzoate-4f): Yield: 84\%; GC-MS: m/z $272\left[\mathrm{M}^{+}\right], 149(30)$, 123(100), 95(30); IR (KBr) v/cm ${ }^{-1} 2965,1738,1605,1503,1238$, 761; ${ }^{1} \mathrm{H}$ NMR (300 MHz, $\mathrm{CDCl}_{3}$ ) $\delta 1.23$ (d, 6H, J 6.9), 2.36 (s, 3H), $3.06(\mathrm{~m}, 1 \mathrm{H}), 6.95(\mathrm{~s}, 1 \mathrm{H}), 7.09(\mathrm{~d}, 1 \mathrm{H}, J 7.9), 7.23(3 \mathrm{H}, \mathrm{m}), 8.25(\mathrm{dd}$, $2 \mathrm{H}, J 5.4,7.8) ;{ }^{13} \mathrm{C} \mathrm{NMR}\left(75 \mathrm{MHz}, \mathrm{CDCl}_{3}\right) \delta 21.0,23.2,27.5,116.0$, 123.0, 126.1, 126.7, 127.5, 132.9, 136.9, 137.4, 148.3, 164.6, 166.3.

2-isopropyl-5-methylphenyl 4-nitrobenzoate (thymyl 4-nitrobenzoate-4g): Yield: 61\%; GC-MS: m/z 299 [M+], 150(100), 120(20), 104(30); IR (KBr) v/cm ${ }^{-1} 2970,1746,1528,1349,1232$, 712; ${ }^{1} \mathrm{H} \mathrm{NMR}\left(300 \mathrm{MHz}, \mathrm{CDCl}_{3}\right) \delta 1.30$ (d, 6H, J 6.9), 2.44 (s, 3H), $3.10(\mathrm{~m}, 1 \mathrm{H}), 7.03$ (s, 1H), 7.18 (d, 1H, J 7.9), 7.35 (d, 1H, J 8.1), 8.44 (d, 2H, $J$ 9.5), 8.48 (d, 2H, $J$ 9.9); ${ }^{13} \mathrm{C} \mathrm{NMR} \mathrm{(75} \mathrm{MHz,} \mathrm{CDCl}_{3}$ ) $\delta$ 21.0, 23.2, 27.6, 122.7, 124.0, 126.9, 127.9, 131.4, 135.2, 137.1, 148.0, 151.1 .

2-isopropyl-5-methylphenyl 4-methoxybenzoate (thymyl 4-methoxybenzoate-4h): Yield: 52\%; GC-MS: $\mathrm{m} / \mathrm{z} 284\left[\mathrm{M}^{+}\right]$, 135(100), 107(10), 77(20); IR (KBr) v/cm ${ }^{-1} 2962,1729,1607,1508$, 1234, 765; ${ }^{1} \mathrm{H}$ NMR (300 MHz, $\left.\mathrm{CDCl}_{3}\right) \delta 1.25$ (d, 6H, J 6.9), 2.38 (s, 3H), 3.10 (m, 1H, J 6.9), 3.93 (s, 3H), 6.98 (s, 1H), 7.04 (d, 2H, $J$ 8.9), 7.09 (d, 1H, $J$ 8.2), 7.28 (d, 1H, $J$ 8.1), 8.22 (d, 2H, $J$ 8.9); ${ }^{13} \mathrm{C}$ NMR $\left(75 \mathrm{MHz}, \mathrm{CDCl}_{3}\right.$ ) $\delta 21.0,23.2,27.5,55.7,114.1,122.3$, $123.2,126.6,127.2,132.4,136.8,137.5,148.5,164.1,165.2$. In agreement of literature. ${ }^{22}$

2-isopropyl-5-methylphenyl 4-methylbenzoate (thymyl 4-methylbenzoate-4i): Yield: 45\%; GC-MS: m/z 268 [M+1, 149(10), 119(100), 91(35); IR (KBr) v/cm ${ }^{-1} 2960,1736,1611,1510,1264$, 753; ${ }^{1} \mathrm{H} \mathrm{NMR}\left(300 \mathrm{MHz}, \mathrm{CDCl}_{3}\right.$, $\delta 1.24(\mathrm{~d}, 6 \mathrm{H}, J 6.9), 2.37$ (s, 3H), $2.48(\mathrm{~s}, 3 \mathrm{H}), 3.09(\mathrm{~m}, 1 \mathrm{H}), 6.97(\mathrm{~s}, 1 \mathrm{H}), 7.08$ (d, 1H, J 7.8), 7.27 (d, $1 \mathrm{H}, J 7.9), 7.35$ (d, 2H, J 8.0), 8.14 (d, 2H, J 8.0); ${ }^{13} \mathrm{C} \mathrm{NMR}(75 \mathrm{MHz}$, $\mathrm{CDCl}_{3}$, $\delta 21.0,21.9,23.2,27.5,123.2,126.6,127.2,127.3,129.5$, $130.4,136.8,137.4,144.5,148.5,165.6$.

\section{Anticholinesterase activity assay}

Was determined using Ellman's method, with adaptations. ${ }^{23,24}$ Aliquots of $5 \mu \mathrm{L}$ of the solutions of carvacrol, thymol and their derivatives at $2 \mathrm{mg} \mathrm{mL}^{-1}$ concentration were spotted on the TLC plate. An equivalent mixture of acetylcholine iodide (ATCI) $\left(1 \mathrm{mmol} \mathrm{L}^{-1}\right)$ and 5,5'-dithiobis-(2-nitrobenzoic) acid (DTNB) $\left(1 \mathrm{mmol} \mathrm{L}^{-1}\right)$ was sprayed on the plate. It was allowed to dry for $10 \mathrm{~min}$ and then $20 \mathrm{U} \mathrm{mL}^{-1}$ of the enzyme solution was sprayed. A yellow color appeared, as a result of the thio anion produced by reacting the enzymatic hydrolysis of the substrate with DTNB. White halos appeared where inhibition of the enzyme occurred. The Eserine salt solution was used as the positive control and the negative control was methanol.

\section{Larvicidal assay}

Aliquots of $1 \mathrm{mg}, 2 \mathrm{mg}, 5 \mathrm{mg}$ and $10 \mathrm{mg}$ of carvacrol, thymol and their derivatives were dissolved in $0.3 \mathrm{ml}$ of dimethylsulfoxide (DMSO) and transferred to beackers. Then, fifty third-stage larvae of Aedes aegypti were added to each solution, and $19.7 \mathrm{~mL}$ of water was added to each beacker. ${ }^{12-14}$ The insecticide Temephos ${ }^{\circledR}$ was used as a positive control and a solution of water and DMSO $1.5 \%$ was used as a negative control.

\section{RESULTS AND DISCUSSION}

Carvacrol and thymol are the main components of the essential oils of oregano, thyme, and savory and used as a chemical defense mechanism against phytopathogenic microorganisms interacting with the cell membrane of the pathogen. ${ }^{25}$ The hydrophobic nature of carvacrol and thymol interact with the lipid bilayer of cytoplasmic 
Table 1. Larvicidal activity $\left(\mathrm{LC}_{50}\right)$ of carvacrol/thymol and derivatives against Aedes aegypti

\begin{tabular}{lclc}
\hline Compound & LC $_{\mathbf{5 0}}(\mathbf{p p m})$ & Compound & $\mathbf{L C}_{\mathbf{5 0}}(\mathbf{p p m})$ \\
\hline Carvacrol & $50,12 \pm 0,20$ & Thymol & $35,71 \pm 0,12$ \\
1a (Carvacryl acetate) & $100,70 \pm 0,83$ & $2 \mathrm{a}$ (Thymyl acetate) & $69,84 \pm 0,67$ \\
1b (Carvacryl hexanoate) & $104,20 \pm 0,74$ & $2 \mathrm{~b}$ (Thymyl hexanoate) & $109,86 \pm 0,66$ \\
1c (Carvacryl benzoate) & $126,52 \pm 1,54$ & 2c (Thymyl benzoate) & $94,40 \pm 1,44$ \\
3d (Carvacryl 4-chlorobenzoate) & $\geq 500$ & $4 \mathrm{~d}$ (Thymyl 4-chlorobenzoate) & $\geq 500$ \\
3e (Carvacryl 4-bromobenzoate) & $\geq 500$ & $4 \mathrm{e}$ (Thymyl 4-bromobenzoate) & $\geq 500$ \\
3f (Carvacryl 4-fluorobenzoate) & $\geq 500$ & $4 \mathrm{f}$ (Thymyl 4-fluorobenzoate) & $\geq 500$ \\
3g (Carvacryl 4-nitrobenzoate) & $\geq 500$ & $4 \mathrm{~g}$ (Thymyl 4-nitrobenzoate) & $\geq 500$ \\
3h (Carvacryl 4-methoxybenzoate) & $94,58 \pm 1,68$ & $4 \mathrm{~h}$ (Thymyl 4-methoxybenzoate) & $23,60 \pm 0,87$ \\
3i (Carvacryl 4-methylbenzoate) & $\geq 500$ & $4 \mathrm{i}$ (Thymyl 4-methylbenzoate) & $\geq 500$ \\
\hline
\end{tabular}

$\mathrm{LC}_{50}=$ Mean Lethal Concentration.

membranes cause loss of integrity and leakage of cellular material such as ions, ATP and nucleic acid. ${ }^{26}$

Generally, the derivatization of hydroxylated monoterpenes results in enhancement of larvicidal activity against Aedes aegypti of newly obtained compounds, because the presence of hydroxyl groups on their parent structures results in decreased potency, preventing substance penetration in the larva cuticle, ${ }^{27-31}$ although this may also result in a decreased activity. ${ }^{32}$ Thus, the synthesis of derivatives of carvacrol/thymol by simple synthetic procedures, such as acylation, consists of a method of obtaining these compounds.

The acylation reactions were performed using readily accessible reagents available from the research group, from which different acid anhydrides and different carboxylic acids derived from benzoic acid. The esterification methodology were carriied with DMAP and DCC, which have the function of catalyzing and increasing the electrophilicity of the carbonyl of the carboxylic acid used, respectively. These reactions are largely employed in organic synthesis because of their high efficiency. ${ }^{33}$

In total, 18 derivatives were obtained, of which compounds $\mathbf{1 b}$, $\mathbf{3 e}$ and $\mathbf{2 e}$ are unpublished and the NMR data of compounds $\mathbf{1 d}$, $\mathbf{1 f}, \mathbf{1 g}, \mathbf{1 i}, \mathbf{2 d}, \mathbf{2 f}, \mathbf{2 g}$ and $\mathbf{2 i}$ are being reported for the first time in literature. The compounds were characterized by GC-MS, IR ${ }^{1} \mathrm{H}$ NMR and ${ }^{13} \mathrm{C}$ NMR. The derivatives yields ranging from 38 to $96 \%$. Among the derivatives obtained from reactions with anhydrides, $(\mathbf{1 a}, \mathbf{1 b}, \mathbf{1 c})$ and $(\mathbf{2 a}, \mathbf{2 b}, \mathbf{2 c})$, the compounds $\mathbf{1 b}$ and $\mathbf{2 b}$, products of the reactions with hexanoic anhydride, showed better yields with of $91 \%$ and $74 \%$, respectively. Among the compounds obtained from the reactions with the derivatives of benzoic acid, $(\mathbf{3 d}, \mathbf{3 e}, \mathbf{3 f}, \mathbf{3 g}, \mathbf{3 h}$, 3i) and (4d, 4e, 4f, 4g, 4h, 4i), those obtained from the halogenated benzoic acid showed better yields, among which compounds $\mathbf{3 f}$ and 4e, showed yields 96 and 89\%, respectively.

The method of Ellman was used to determine inhibition of acetylcholinesterase. The formation of a white halo around the TLC "spots" is indicative of AChE enzyme inhibition. The diameter of the halos were measured $(\mathrm{cm})$, and compared with the positive standard Eserine $(1.4 \mathrm{~cm})$. Only compounds 5-isopropyl-2-methylphenyl acetate (1a) and 2-isopropyl-5-methylphenyl hexanoate (2b) showed positive results, with the diameters 1.2 and $1.4 \mathrm{~cm}$, respectively, close to the positive control Eserine $(1.4 \mathrm{~cm})$ and can be represent promising potential for inhibition of AChE.

The larvicidal tests were carried out to determine the lethal concentration $\left(\mathrm{LC}_{50}\right)$ against instar III larvae of Aedes aegypti, and the results are showed in Table 1. According to literature, compounds with $\mathrm{LC}_{50}$ values of up to $100 \mathrm{ppm}$ are considered to be excellent larvicidal agents. ${ }^{34}$ The compounds carvacrol and thymol presented an excellent activity, showing $\mathrm{LC}_{50}$ values of $50.12 \pm 0.20$ and 35.71 $\pm 0.12 \mathrm{ppm}$, respectively, and these results are in agreement with data reported in the literature. ${ }^{32}$

Although the hydroxylated monoterpene derivatives show better activity than their parent compounds, the carvacryl/thymyl acetate (1a, 2a), carvacryl/thymyl hexanoate (1b, 2b), and carvacryl/thymyl benzoate $(\mathbf{1 c}, \mathbf{2 c})$ showed a reduction in larvicidal activity, and similar results were previously found for the carvacryl/thymyl acetate and carvacryl/thymyl benzoate. ${ }^{32}$

The aromatic esters of carvacol/thymol containing halogen or nitro group in para position of aromatic ring were inactive. In these compounds, it is observed that the presence of electron withdrawing groups results in a significant decrease in the larvicidal activity.

The derivative, thymyl 4-methoxy-benzoate $\mathbf{( 4 h )}$, presented the best activity, showing $\mathrm{LC}_{50}$ value of $23.60 \pm 0.87 \mathrm{ppm}$. In the compounds thymyl 4-methoxy-benzoate (3h) and carvacyl 4-methoxy-benzoate (4h), the presence of an aromatic ring a with a methoxyl group improve the activity. The comparison of $\mathrm{LC}_{50}$ values of the two derivatives (3h) and (4h) showed that the derivative (4h) was more active. Thus, the position of substituent in the aromatic ring may affect the larvicidal activity. ${ }^{31}$ Temephos ${ }^{\circledR}\left(O, O^{\prime}\right.$-(thiodi-4,1phenylene)bis(O,O-dimethyl phosphorothioate) was used as control positive and showed $\mathrm{LC}_{50}$ value of $1.4 \pm 0.2 \mathrm{ppm}$.

\section{CONCLUSIONS}

The results show that the methodology used provides the expectant products, and some compounds have the potential to inhibit the enzyme acetylcholinesterase besides larvicidal activities. It has been demonstrated that structural features can contribute to the of the larvicidal activity of monoterpenes. Hydroxyl esterification showed changes in these activities, both the increase and the decrease of activity against Aedes aegypti. The addition of a benzoate group containing electron withdrawing substituents on the aromatic ring resulted in the inactivation of the compound against the mosquito larvae. The presence of electron-donor groups resulted in a significant increase in activity, such as thymyl 4-methoxibenzoate. We hope that these results can contribute to the search for safer alternatives to pest control and the search for new bioactive molecules.

\section{SUPPLEMENTARY MATERIAL}

NMR and GC-MS spectra, as well as chromatograms and fragmentation proposals are available at http://quimicanova.sbq.org. br, in the form of a PDF file, with free access. 


\section{ACKNOWLEDGEMENTS}

The authors thank the brazilian agencies CAPES - Brazil and $\mathrm{CNPq}$ - Brazil for fellowships and financial support.

\section{REFERENCES}

1. Coccimiglio, J.; Alipour, M.; Jiang, Z. H.; Gottardo, C.; Suntres, Z.; Oxid. Med. Cell. Longevity 2016, 1.

2. Govindarajan, M.; Rajeswary, M.; Hoti, S. L.; Benelli, G.; Res. Vet. Sci. 2016, 104, 77.

3. Gholijani, N.; Gharagozloo, M.; Farjadian, S.; Amirghofran, Z.; Immunotoxicology 2016, 13, 157.

4. Zhang, Z.; Yang, T.; Mi, N.; Wang, Y.; Li, G.; Wang, L.; Xie, Y.; Int. Biodeterior. Biodegrad. 2016, 106, 157.

5. Cechinel Filho, V.; Yunes, R. A.; Quim. Nova 1998, 21, 99.

6. Alokam, R.; Jeankumar, V. U.; Sridevi, J. P.; Matikonda, S. S.; Peddi, S.; Alvala, M.; Yogeeswari, P.; Sriram, D.; J. Enzyme Inhib. Med. Chem. 2014, 29, 547.

7. Mathela, C. S.; Singh, K. K.; Gupta, V. K.; Acta Pol. Pharm. 2010, 67, 375 .

8. Nikumbh, V. P.; Tare, V. S.; Mahulikar, P. P.; J. Sci. Ind. Res. 2003, 62, 1086.

9. Morais, S. M.; Vila-Nova, N. S.; Bevilaqua, C. M. L.; Rondon, F. C.; Lobo, C. H.; Moura, A. D. A. A. N.; Sales, A. D.; Rodrigues, A. P. R.; Figuereido, J. R.; Campello, C. C.; Wilson, M. E.; Andrade Júnior, H. F.; Bioorg. Med. Chem. 2014, 22, 6250.

10. Damasceno, S. R.; Oliveira, F. R. A.; Carvalho, N. S.; Brito, C. F.; Silva, I. S.; Sousa, F. B. M.; Silva, R. O.; Sousa, D. P.; Barbosa, A. L. R.; Freitas, R. M.; Medeiros, J. V. R.; Life Sci. 2014, 94, 58.

11. Tabanca, N.; Bernier, U. R.; Agramonte, N. M.; Tsikolia, M.; Bloomquist, J. R.; Curr. Org. Chem. 2016, 20, 2690.

12. Tabanca, N.; Avonto, C.; Wang, M.; Parcher, J. F.; Ali, A.; Demirci, B.; Raman, V.; Khan, I. A.; J. Agric. Food Chem. 2013, 61, 12283.

13. Carvalho, A. F. U.; Melo, V. M. M.; Craveiro, A. A.; Machado, M. I. L.; Bantim, M. B.; Rabelo, E. F.; Mem. Inst. Oswaldo Cruz 2003, 98, 569.

14. Lima, M. A. A.; Oliveira, F. F. M.; Gomes, G. A.; Lavor, P. L.; Santiago, G. M. P.; Nagao-Dias, A. T.; Arriaga, A. M. C., Lemos, T. L. G.; Carvalho, M. G.; Afr. J. Biotechnol. 2011, 10, 11716.

15. Kurt, B. Z.; Gazioglu, I.; Dag, A.; Salmas, R. E.; Kayık, G.; Durdagi, S.; Sonmez, F.; Bioorg. Med. Chem. 2017, 25, 1352.

16. Gade, S.; Rajamanikyam, M.; Vadlapudi, V.; Nukala, K. M.; Aluvala, R.; Giddigari, C.; Karanam, N. J.; BaruA, N. C.; Pandey, R.; Upadhyayula, V. S. V.; Sripadi, P.; Amanchy, R.; Upadhyayula, S. M.; Biochim. Biophys. Acta 2017, 1861, 541.
17. Alout, H.; Labbé, P.; Berthomieu, A.; Djogbénou, L.; Leonetti1, J.; Fort, P.; Weill, M.; PloS One 2012, 7, e47125.

18. Fonseca, T. S.; Silva, M. R.; Oliveira, M. D. C. F.; Lemos, T. L. G.; Araújo, R. M.; Mattos, M. C.; Appl. Catal., A 2015, 492, 76.

19. Pires, L. F.; Costa, L. M.; Almeida, A. A. C.; Silva, O. A.; Cerqueira, G. S.; Sousa, D. P.; Freitas, R. M.; Neurochem. Res. 2014, 39, 758.

20. Angeles-López, G.; Pérez-Vásquez, A.; Hernández-Luis, F.; DécigaCampos, M.; Bye, R.; Linares, E.; Mata, R.; J. Ethnopharmacol. 2010, 131,425

21. Narender, T.; Khaliq, T.; Singh, A. B.; Joshi, M. D.; Mishra, P.; Chaturvedi, J. P.; Srivastavab, A. K.; Maurya, R.; Agarwal, S. C.; Eur. J. Med. Chem. 2009, 44, 1215.

22. Ortar, G.; Morera, L.; Moriello, A. S.; Morera, E.; Nalli, M.; Di Marzo, V.; De Petrocellis, L.; Bioorg. Med. Chem. Lett. 2012, 22, 3535.

23. Ellman, G. L.; Courtney, K. D.; Andres, V.; Featherstone, R. M.; Biochem. Pharmacol. 1961, 7, 88.

24. Rhee, I. K.; Van de Meent, M.; Ingkaninan, K.; Verpoorte, R.; J. Chromatogr. 2001, 915, 217.

25. Numpaque, M. A.; Oviedo, L. A.; Gil, J. H.; García, C. M.; Durango, D. L.; Tropical Plant Pathology 2011, 36, 3.

26. Nostro, A.; Roccaro, A. S.; Bisignano, G.; Marino, A.; Cannatelli, M. A.; Pizzimenti, F. C.; Cioni, P. L.; Procopio, F.; Blanco, A. F.; J. Med. Microbiol. 2007, 56, 519.

27. Lazarević, J.; Kolarević, A.; Đorđević, A.; Stojanović, G.; Šmelcerović, A.; Ciuffreda, P.; Santaniello, E.; Acta Chim. Slov. 2017, 64, 603.

28. López, O.; Fernández-Bolaños, J. G.; Gil, M. V.; Green Chem. 2005, 7, 431.

29. Santos, S. R. L.; Silva, V. B.; Melo, M. A.; Cardoso, A. V.; Santos, R. L. C.; Sousa, D. P.; Cavalcanti, S. C. H.; Chemosphere 2011, 84, 150.

30. Santos, S. R. L.; Silva, V. B.; Melo, M. A.; Barbosa, J. D. F.; Santos, R. L. C.; Sousa, D. P.; Cavalcanti, S. C. H.; Vector Borne Zoonotic Dis. 2010, 10, 1049.

31. Pandey, S. K.; Tandon, S.; Ahmad, A.; Singh, A. K.; Pest. Manag. Sci. 2013, 69, 1235.

32. Silva, V. B.; Travassos, D. L.; Nepel, A.; Barison, A.; Costa, E. V.; Scotti, L.; Scotti, M. T.; Mendonça-Junior, F. J. B.; Santos, R. L. C.; Cavalcanti, S. C. H.; J. Arthropod-Borne Dis. 2017, 11, 315.

33. Carey, F. A.; Sundberg, R. J.; Advanced Organic Chemistry, Part A: Structure and Mechanisms. $5^{\text {th }}$ ed., Springer: Charlottesville, 2007.

34. Cheng, S. S.; Chang, H. T.; Chang, S. T.; Tsai, K. H.; Chen, W. J.; Bioresour. Technol. 2003, 89, 99. 